\title{
DESAIN DAN IMPLEMENTASI SISTEM KENDALI CNC ROUTER MENGgunAKAN PC UNTUK FLAME CUTTING MACHINE
}

\author{
Roni Permana Saputra ${ }^{1}$, Anwar Muqorrobin ${ }^{1}$, Arif Santoso ${ }^{1}$, Teguh Pudji Purwanto ${ }^{2}$ \\ ${ }^{1}$ Pusat Penelitian Tenaga Listrik dan Mekatronik - LIPI \\ Komp. LIPI Bandung, Jl Sangkuriang, Gd 20, Lt 2, Bandung, \\ Jawa Barat 40135, Indonesia. \\ permana.saputra@yahoo.co.id \\ ${ }^{2}$ Jurusan Teknik Mesin dan Industri - Universitas Gadjah Mada \\ Jl. Grafika No. 2, Yogyakarta 55281, Indonesia \\ teguhpp@yahoo.com
}

Diterima: 13 April 2011; Direvisi: 25 April 2011; Disetujui: 2 Mei 2011;

Terbit online: 7 Juli 2011.

\begin{abstract}
Abstrak
Makalah ini membahas tentang desain sistem kendali router berbasis computer numerical control (CNC) menggunakan personal computer (PC), untuk diimplementasikan di flame cutting machine (FCM). NC-Code yang diinputkan ke komputer diterjemahkan menjadi sinyal perintah yang dikirimkan PC ke microcontroller untuk mengendalikan gerakkan end effector mesin pada sumbu $\mathrm{X}$ dan sumbu $\mathrm{Y}$ secara simultan berdasarkan hasil perhitungan interpolasi linier dan interpolasi sirkular pada PC. Sistem kendali ini diimplementasikan pada FCM dengan menghubungkan output kendali dari microcontroller dengan driver aktuator FCM berupa motor DC. Hasil yang diperoleh berupa suatu prototipe sistem kendali router CNC untuk diimplementasikan di FCM dan mampu melakukan interpolasi linier dan interpolasi sirkular.

Kata kunci: kontrol CNC, CNC based PC, routerCNC.

Abstract

This paper focuses on design of router control systems based on computer numerical control (CNC) using personal computer (PC) implemented in flame cutting machine (FCM). NC-Code entered into the computer translated to be a command signal sent by the PC to a microcontroller to control the end effector's movement along the $X$ and $Y$ axis simultaneously based on linear and circular interpolations calculation on the PC. This control system is implemented on FCM by connecting the output control of the microcontroller with the driver actuator of the FCM in the form of a DC motor. The obtained result is in the form of a CNC router control system prototype to be implemented in the FCM which is capable to perform linear interpolation and circular interpolation.
\end{abstract}

Keywords: CNC control, CNC based PC, router CNC.

\section{Pendahuluan}

Aplikasi teknologi computer numerical control (CNC) dewasa ini telah berkembang luasuntuk mesin-mesin perkakas di industri manufaktur yang membutuhkan keunggulan dalam hal fleksibilitas, akurasi, dan kemampuan pengulangan dibandingkan mesin konvensional [1]. Mesin ini harus mampu mengulang gerakanidentik dengan jumlah banyak dengan ketelitian tinggi. Mesin CNC bekerja berdasarkan NC-Codeyang diinputkan oleh operator pada perangkat kendalinya [2]. Jika suatu program telah dibuat untuk membuat suatu produk, maka operator hanya tinggal mengulangi proses running dari program itu sebanyak produk yang ingin dihasilkan.

Salah satu jenis mesin yang mengunakan teknologi CNC ialah mesin pemotong plat dengan berbagai macam model alat irisnya, diantaranya flame cutting machine produk LTech Peacemaker yang terdapat dilaboratorium CNC Teknik Mesin UGM [3]. Mesin ini memiliki kemampuan memotong platdengan kontur sesuai dengan program CNC yang diinputkan. Mesin ini mengalami kerusakan pada sistem pengontrol CNC, sehingga tidak dapat lagi dioperasikan. Salah satu kendala yang ada adalah sulit dan mahalnya suku cadang mesin.

Sementara itu, saat ini sudah banyak dikembangkan penelitian mengenai pengendalian mesin CNC berbasis PC. Hal ini banyak dilakukan untuk menghasilkan mesin CNC yang lebih murah, serta dengan suku cadang yang mudah didapat [4] [5].

Untuk itu, pada penelitian ini dilakukan desain sistem kendali router berbasis CNC menggunakan PC dengan tetap mempertahankan metode pengendalian mesin dengan NC-Code untuk dapat diimplementasikan di flame cutting 
machine. Adapun tujuan dari penulisan makalah ini adalah untuk melaporkan unjuk kerja dari hasil desain sistem kendali diatas dengan melakukan eksperimen di laboratorium

\section{TEORI}

Pada perancangan ini, mesin yang dikendalikan berupa mesin CNC flame cutting machine dengan geometri kartesian yang memiliki gerakan end effector mesin dalam dua arah yang independen, yaitu arah $\mathrm{x}$, dan arah $\mathrm{y}$. Untuk mengatur gerakan kedua aktuator secara simultan dilakukan dengan interpolasi linear untuk membentuk garis lurus, dan interpolasi sirkular untuk membentuk busur lingkaran

\section{A. Interpolasi Linear}

Untuk menghasilkan garis lurus, digunakan pendekatan dengan runtutan gerakan-gerakan pendek yang terkoordinasi oleh sistem pengendali. Metode runtutan gerakan-gerakan ini dinamakan quasi continuous movement [6].

Untuk menggerakkan end effektor membentuk garis lurus dari titik $(\mathrm{x} 1, \mathrm{y} 1)$ ke titik $(\mathrm{x} 2, \mathrm{y} 2)$, end effektor digerakkan $\mathrm{nx}$ step dalam arah sumbu $\mathrm{x}$ dan ny step dalam arah sumbu y [6]. Untuk nilai gradien positif, apabila koordinat posisi end effector saat ini berada diatas kurva, maka step gerakan berikutnya adalah ke kanan, dan apabila kooordinat posisi alat potong saat ini berada di bawah kurva, maka step gerakan motor berikutnya adalah ke atas. Untuk gradien garis negatif, gerakan end effector ke arah sebaliknya. Metode yang dijelaskan pada bagian ini disebut dengan metode Direct Function Estimation Method (Metode DFE) [7].

\section{B. Interpolasi Sirkular}

Interpolasi sirkular digunakan untuk membentuk busur lingkaran. Proses pembuatan busur lingkaran ditunjukkan pada Gambar 1. Busur lingkaran dapat dinyatakan dengan menentukan titik awal $(\mathrm{x} 1, \mathrm{y} 1)$, titik akhir $(\mathrm{x} 2, \mathrm{y} 2)$,

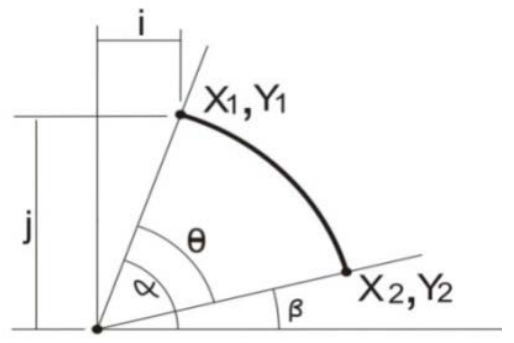

(a) arah putar dan posisi relatif pusat lingkaran terhadap titik awal $(i, j)$. Maka busur lingkaran yang dimaksud ditunjukkan pada Gambar 1a [6].

Nilai a merupakan posisi sudut titik awal $(\mathrm{x} 1, \mathrm{y} 1)$ terhadap titik pusat busur lingkaran. Nilai b merupakan posisi sudut titik akhir (x2,y2) terhadap titik pusat busur lingkaran. Nilai $\theta$ merupakan posisi sudut titik-titik sepanjang busur (xn,yn) terhadap titik pusat busur.

Busur lingkaran pada Gambar 1 didekati dengan poligon bersegi banyak seperti pada Gambar 1b [6]. Pada Gambar 1b diperlihatkan bahwa untuk mendapatkan busur lingkaran yang mulus dapat dilakukan dengan membuat segmen garis sekecil mungkin sedemikian rupa sehingga nilai t yang diperoleh berupa toleransi. Untuk membuat segmen garis poligon dari busur lingkaran dilakukan dengan membagi busur lingkaran dengan sudut $\theta$ menjadi juring-juring dengan sudut g. Maka akan dihasilkan segmensegmen garis dimana segmen garis ke-n memiliki koordinat titik awal (xn-1, yn-1) dan koordinat titik akhir (xn,yn). Setelah diperoleh titik awal dan titik akhir segmen garis poligon tersebut, kemudian dilakukan interpolasi linier [6].

\section{Pengendalian Mesin Menggunakan NC- Code}

Mesin CNC bekerja untuk memotong benda kerja dengan lintasan pemotongan sesuai dengan kode-kode numerical control yang telah diberikan yang dikenal dengan NC-Code. NC-Code yang digunakan pada perancangan sistem kendali pada penelitian ini ditunjukkan pada Tabel 1 [6].

\section{PelaksanaAn Penelitian}

Penelitian ini terdiri dari tahap perancangan sistem pengendali router CNC yang terdiri dari perangkat keras dan perangkat lunak, pengujian linieritas, pengujian repeatabilitas, pengujian interpolasi linear, dan pengujian interpolasi sirkular. Diagram blok dari sistem kendali yang dibuat, ditunjukkan pada Gambar 2.

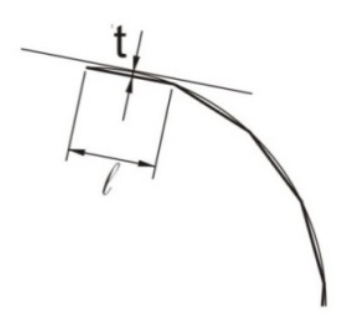

(b)

Gambar 1. Proses pembuatan busur lingkaran(a) Parameter-parameter pada busur lingkaran, (b) Poligon pendekatan busur lingkaran. 
Tabel 1.

Daftar NC-Code.

\begin{tabular}{ll}
\hline Kode & Eksekusi yang dilakukan \\
\hline G00 & Interpolasi linear tanpa pemotongan \\
\hline G01 & $\begin{array}{l}\text { Interpolasi linear dengan pemotongan dengan } \\
\text { dimensi normal }\end{array}$ \\
\hline G02 & $\begin{array}{l}\text { Interpolasi sirkular cw dengan pemotongan } \\
\text { dengan dimensi normal }\end{array}$ \\
\hline G03 & $\begin{array}{l}\text { Interpolasi sirkular ccw dengan pemotongan } \\
\text { dengan dimensi normal }\end{array}$ \\
\hline G04 & $\begin{array}{l}\text { Waktu penundaan dengan lamanya waktu } \\
\text { ditentukan dengan nilai F }\end{array}$ \\
\hline G10 & $\begin{array}{l}\text { Interpolasi linear dengan pemotongan dengan } \\
\text { dimensi panjang (10x) }\end{array}$ \\
\hline G11 & $\begin{array}{l}\text { Interpolasi linear dengan pemotongan dengan } \\
\text { dimensi pendek }\end{array}$ \\
\hline G20 & $\begin{array}{l}\text { Interpolasi sirkular cw dengan pemotongan } \\
\text { dengan dimensi panjang(10x) }\end{array}$ \\
\hline G21 & $\begin{array}{l}\text { Interpolasi sirkular cw dengan pemotongan } \\
\text { dengan dimensi pendek }\end{array}$ \\
\hline G30 & $\begin{array}{l}\text { Interpolasi sirkular ccw dengan pemotongan } \\
\text { dengan dimensi panjang (10x) }\end{array}$ \\
\hline G31 & $\begin{array}{l}\text { Interpolasi sirkular ccw dengan pemotongan } \\
\text { dengan dimensi pendek }\end{array}$ \\
\hline G90 & Pemrograman dimensi absolut \\
\hline G91 & Pemrograman dimensi inkrimental \\
\hline M00 & $\begin{array}{l}\text { Program berhenti sampai ditekan kembali } \\
\text { tombol jalankan. }\end{array}$ \\
\hline Akhir dari program \\
\hline
\end{tabular}

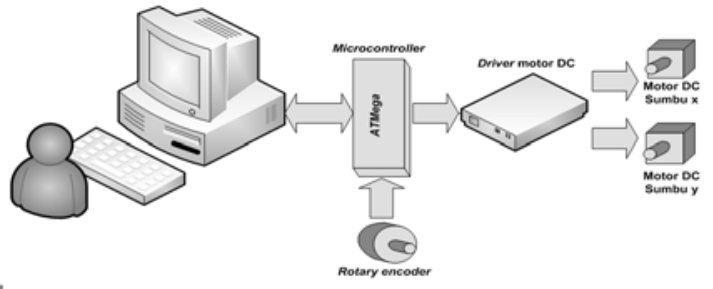

Gambar 2. Diagram blok rancangan sistem pengendali router $\mathrm{CNC}$.

\section{A. Perancangan Perangkat Keras}

Perangkat keras sistem pengendali router CNC ini berupa PC dan rangkaian elektronika yang terintegrasi untuk melakukan pengendalian aktuator. Aktuator yang dikendalikan berupa dua motor DC yang masing-masing menggerakkan sumbu X dan sumbu Y. Rangkaian elektronika pada sistem ini berupa rangkaian sistem microcontroller untuk komunikasi dengan PC sebagai pengendali, rangkaian penggerak motor DC, dan rotary encoder untuk feed back posisi. Gambar 3 menunjukkan skema keseluruhan rangkaian elektronika sistem pengendali router CNC.

Microcontroller menerima data posisi dari PC. Kemudian microcontroller mengaktifkan aktuator agar end effector bergerak ke posisi yang diperintahkan. Sinyal feed back dari rotary

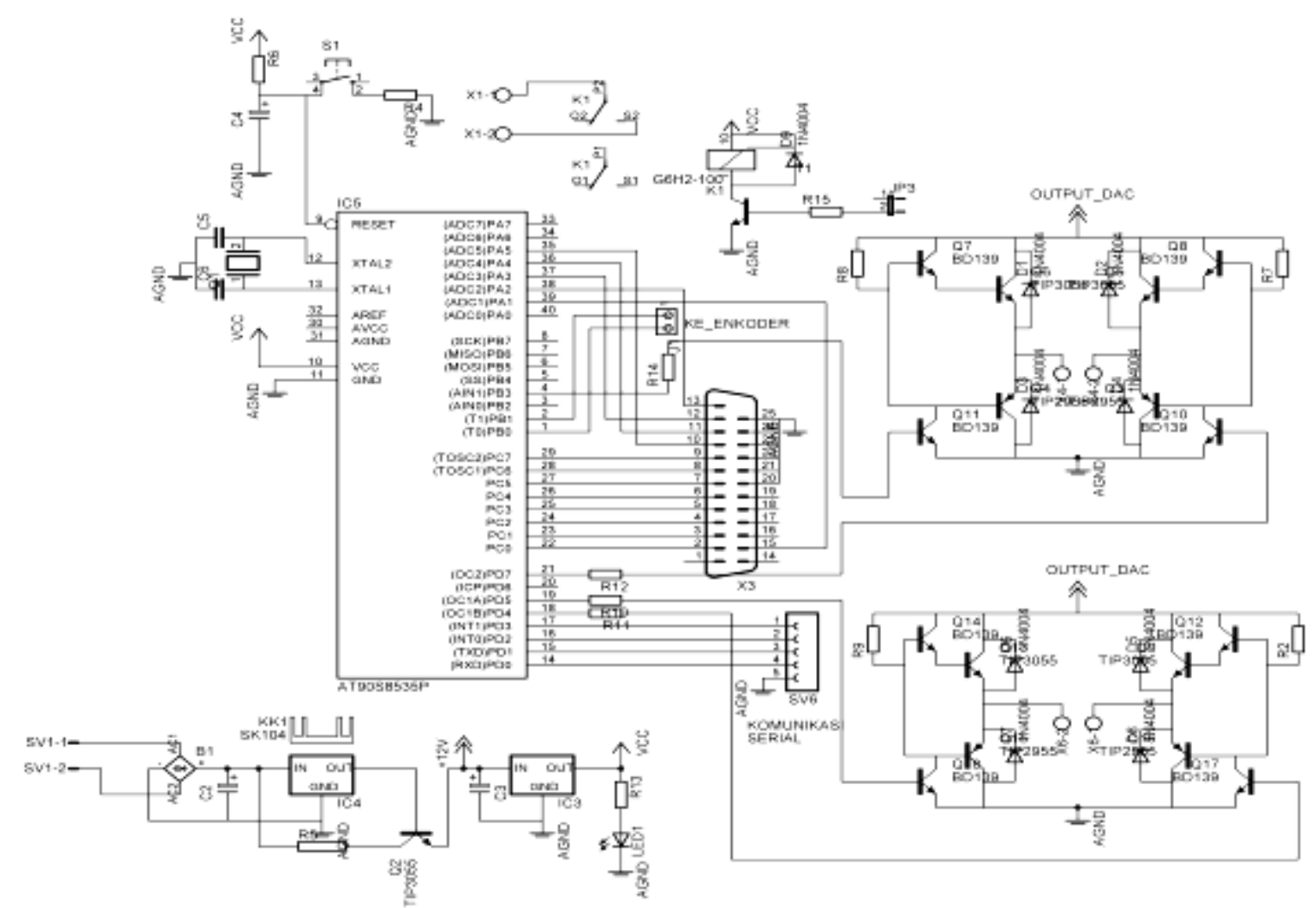

Gambar 3. Skema rangkaian elektronik pengendali router CNC. 


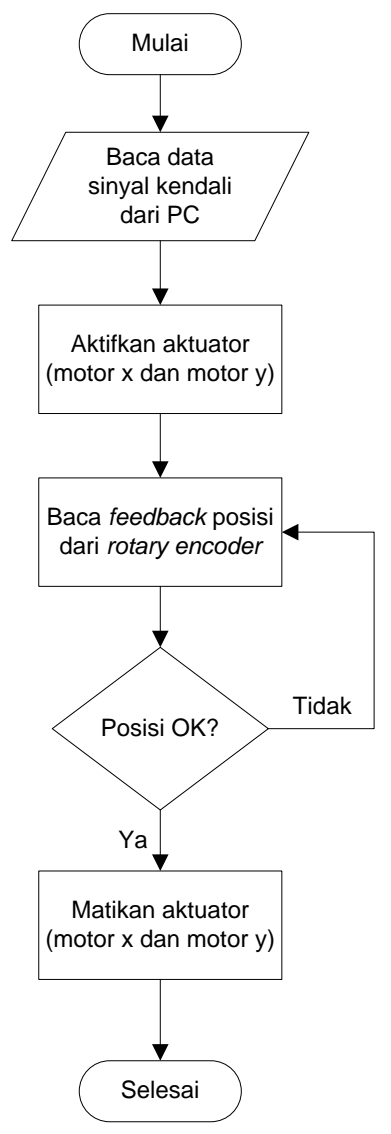

Gambar 4. Algoritma perangkat lunak kendalidi microcontroller.

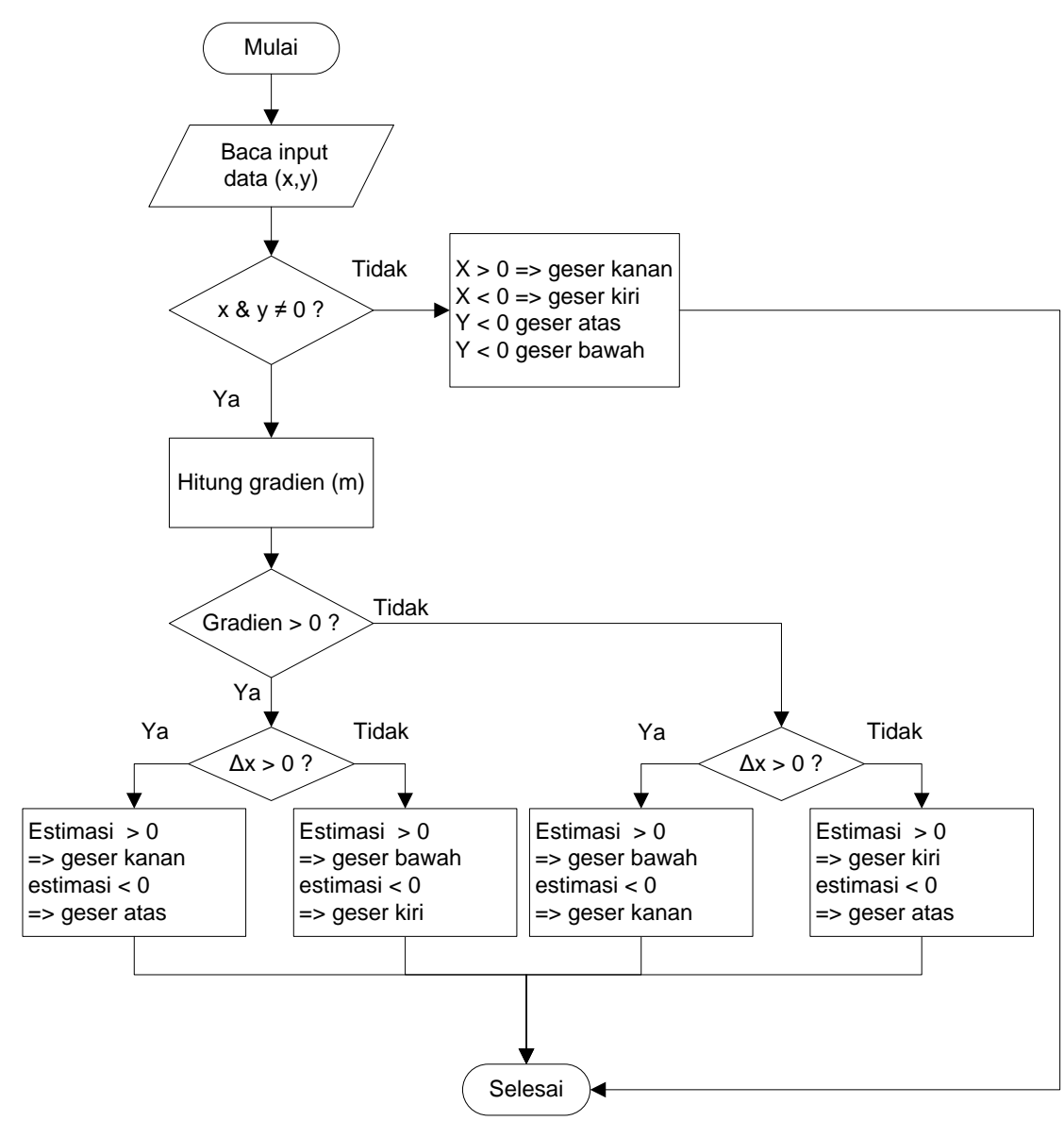

encoder diterima oleh microcontroller untuk memastikan end effector telah bergerak ke posisi yang tepat.

Perangkat lunak di komputer berfungsi untuk menerjemahkan NC-Code yang diinputkan dengan proses interpolasi linier atau interpolasi sirkular berdasarkan input program NC-Code dan sebagai antar muka antara operator dengan mesin. Pada Gambar 5, ditunjukkan algoritma proses interpolasi linier dan interpolasi sirkular pada komputer.

Untuk interpolasi linier (Gambar 5a), input yang dibutuhkan nilai koordinat tujuan $(\mathrm{x} 2, \mathrm{y} 2)$. Sedangkan nilai koodinat awal $(\mathrm{x} 1, \mathrm{y} 1)$ sudah tersimpan di memori. Dari input tersebut kemudian dihitung nilai gradien (m) [7]. Kemudian dari gradien tersebut bisa dihitung nilai fungsi etimasi dari titik sesaat end effector [7]. Dari perhitungan fungsi estimasi dan nilai dari $\Delta \mathrm{x}$, ditentukan pergerakan end effector kekiri, kanan, atas, atau bawah yang selanjutnya sinyal kendali tersebut dikirimkan PC ke microcontroller.

Untuk interpolasi sirkular (Gambar 5b), input yang dibutuhkan koordinat tujuan $(\mathrm{x} 2, \mathrm{y} 2)$, arah busur, dan posisi titik pusat (i,j). Dari nilai input (a)

Gambar 5. Diagram alir perangkat lunak kendali di PC(a) Diagram alir interpolasi linier (b) Diagram alir interpolasi sirkular.

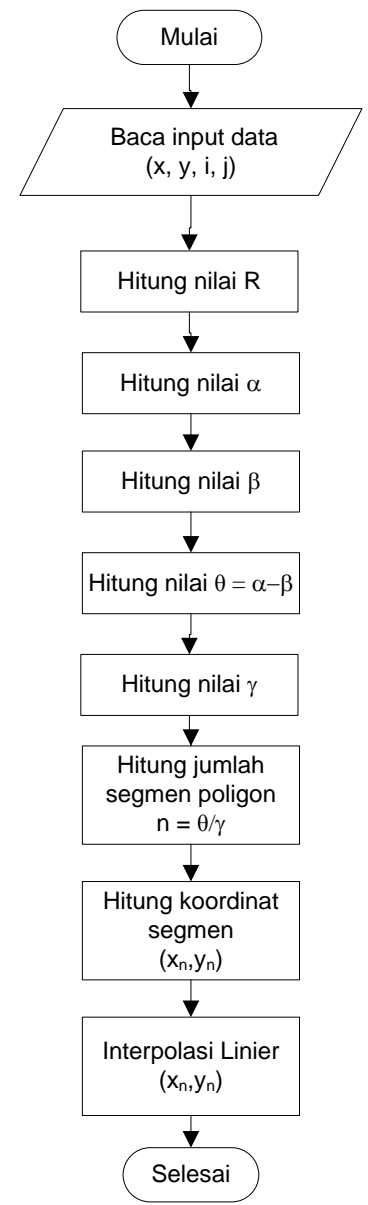

(b) 
tersebut dihitung nilai jari jari R [6]. Selanjutnya dihitung nilai $\alpha$ dan $\beta$ [6]. Nilai $\theta$ merupakan selisih dari $\alpha$ dan $\beta$ seperti pada Gambar 4 . Selanjutnya untuk membagi busur menjadi poligon, nilai $\gamma$ dihitung sebagai sudut pembagi [6]. Setelah didapat poligon segi-n, dihitung nilai koordinat tiap-tiap ruas garis poligon tersebut (xn,yn) [6]. Setelah didapat koordinat masingmasing ruas garis poligon tersebut, tinggal dilakukan interpolasi linier sesuai diagram alir pada Gambar 5a.

Selain sebagai kendali utama, PC juga digunakan sebagai sarana perantara antara operator dengan sistem pengendali, dimana operator akan menginputkan program $\mathrm{NC}$-Code untuk menggerakkan mesin ke PC. Maka dibuat tampilan User Interface di PC. Tampilan user interface dirancang sedemikian hingga dapat menampilkan layar yang memuat $N C$-Code yang diimputkan, hasil kompile, dan gambar simulasi pergerakan mesin dari program yang diinputkan. Selain layar tersebut, user interface juga dirancang agar panel kendali yang terdapat didalamnya mudah untuk mengoperasikan mesin.

\section{B. Pengujian Linieritas}

Pengujian linieritas dilakukan dengan menginputkan program gerakan lurus sepanjang $50 \mathrm{~mm}$ sampai dengan $200 \mathrm{~mm}$ secara bertahap pada sistem kendali untuk gerakkan arah sumbu $\mathrm{x}$ dan sumbu y. Gambar 6 menunjukkan proses pengujian gerakan end effector mesin.

Setelah mesin dijalankan, end effector mesin yang telah dipasangi spidol dan diletakkan white board di bawahnya seperti terlihat pada Gambar 6

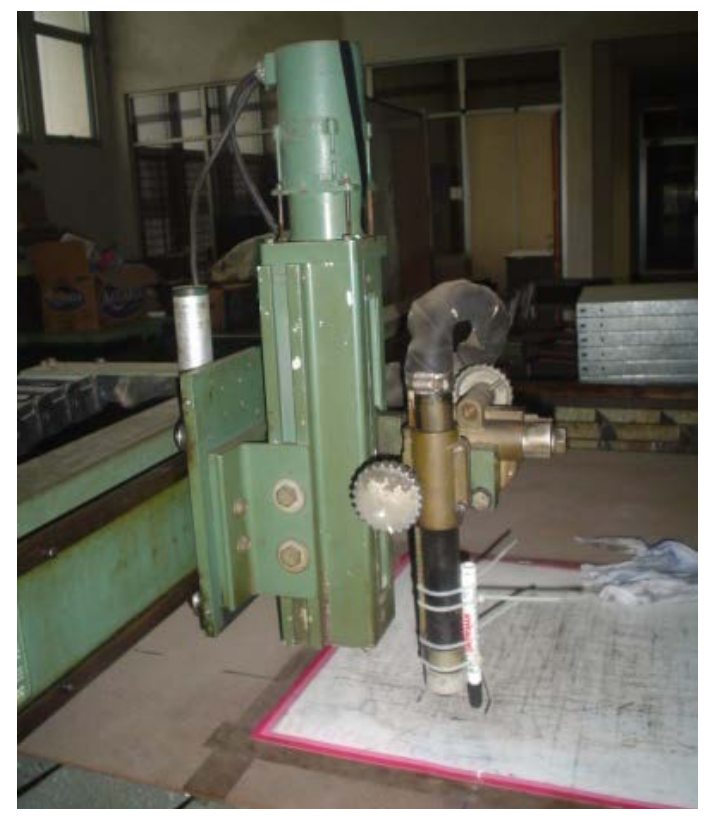

Gambar 6. Pengujian gerakan end effector mesin. akan melakukan gerakkan sesuai progam yang diinputkan. Selanjutnya pergerakan end effector mesin yang tergambar di whiteboard diukur panjang gerakkan aktual yang terbentuk berdasarkan gambar tersebut, kemudian dihitung koefisien regresi linier dari nilai-nilai terukur tersebut.

\section{Pengujian Repeatabilitas}

Pengujian repeatabilitas dilakukan dengan menginputkan program gerakan lurus sepanjang $100 \mathrm{~mm}$ berulang-ulang sebanyak seratus kali. Selanjutnya pergerakan end effector mesin yang tergambar di white board diukur panjang gerakkan aktualnya, kemudian dihitung simpangan standar deviasi dari nilai terukur tersebut.

\section{Pengujian Interpolasi Linier}

Pengujian kemampuan interpolasi linear dilakukan dengan menginputkan program $\mathrm{NC}$ Code untuk membentuk suatu pola yang terdiri dari garis-garis lurus. Kemudian, NC-Code ang telah diinputkan tersebut disimulasikan dan dieksekusi untuk kemudian diamati hasilnya.

\section{E. Pengujian Interpolasi Sirkular}

Pengujian kemampuan interpolasi sirkular dilakukan dengan menginputkan program $N C$ Code untuk membentuk suatu pola yang terdiri dari busur-busur lingkaran.Kemudian, NC-Code yang telah diinputkan tersebut disimulasikan dan dieksekusi untukkemudian diamati hasilnya.

\section{Hasil dan Pembahasan}

Dari penelitian ini, dihasilkan sistem pengendali router berbasis CNC untuk diimplementasikan di flame cutting machine. Pada Gambar 7 ditunjukkan tampilan user interface sistem kendali di PC.

Tampilan layar utama sistem kendali (Gambar 7a) terdiri dari layar input yang berfungsi untuk memasukan input program NC-Code yang akan disimulasikan ataupun dieksekusi, dan layar output berfungsi untuk menampilkan baris program yang sedang dieksekusi. Jika program NC-Code yang telah diinputkan disimulasikan, maka akan muncul tampilan layar simulasi (Gambar 7b) yang menunjukkan simulasi gerakan end effector mesin sesuai dengan $N C$ Code yang diinputkan.

Fungsi dari tombol-tombol yang terdapat pada tampilan utama sistem kendali ditunjukkan pada Tabel 2. Selanjutnya, hasil pengujian linearitas positioning end effector mesin ditunjukkan pada Tabel 3 dan Gambar 8. 


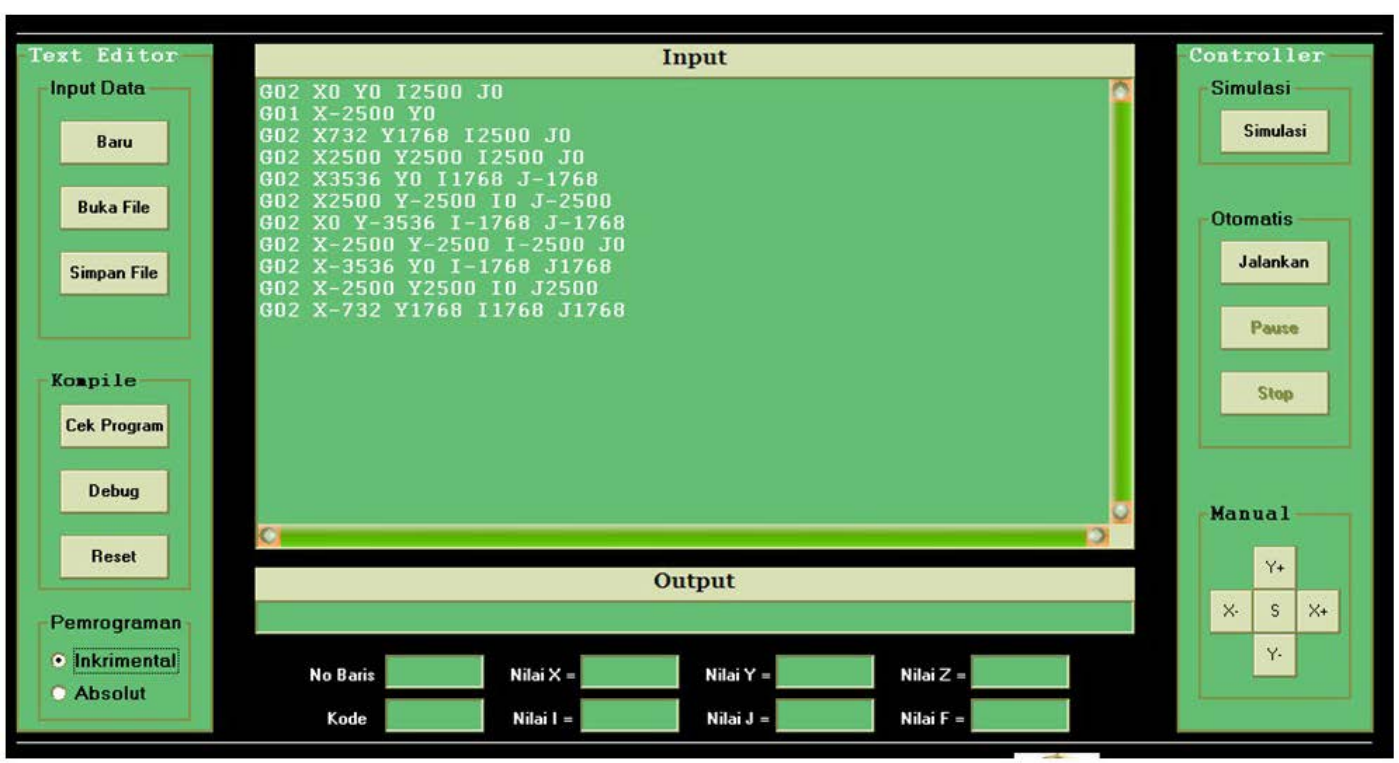

(a)

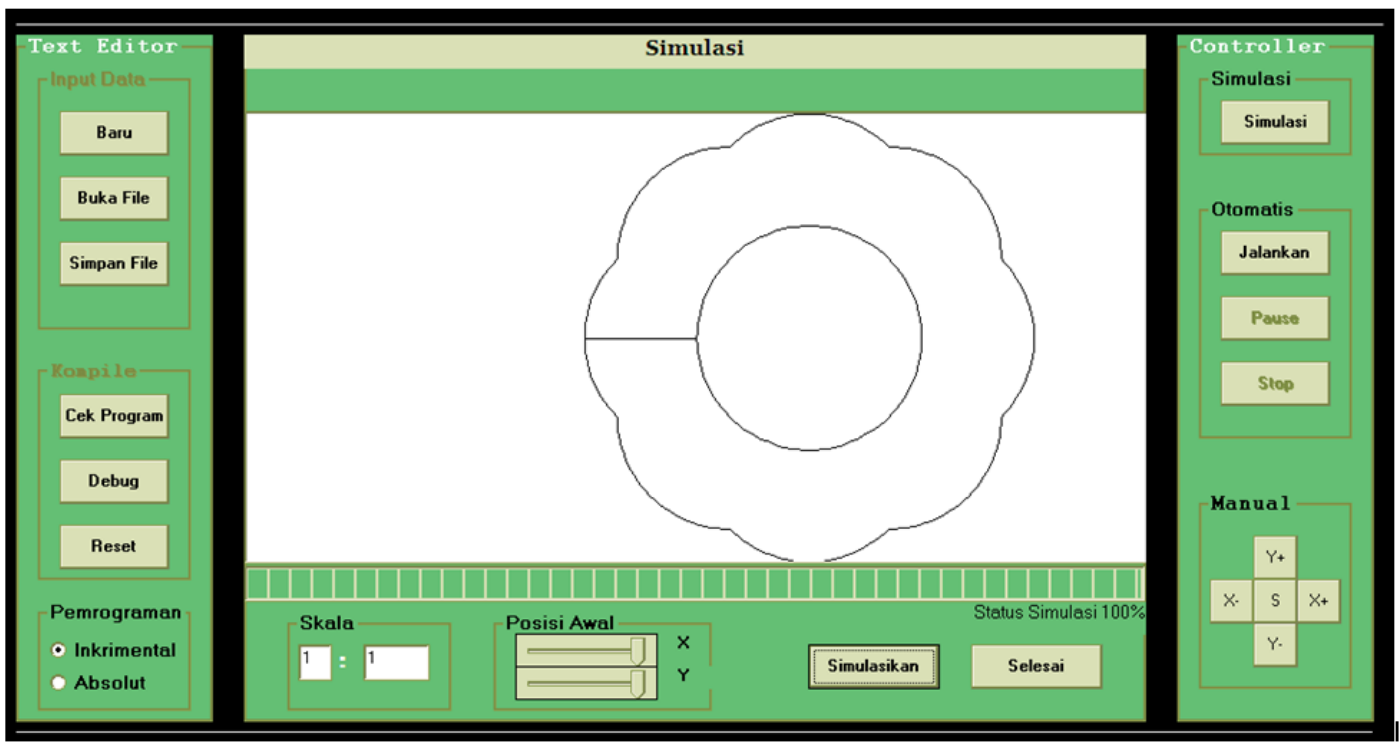

(b)

Gambar 7. Tampilan user interface sistem kendali di PC (a) Tampilan layar utama, (b) Tampilan layar simulasi.

Tabel 2.

Fungsi tombol-tombol pada tampilan utama sistem kendali.

\begin{tabular}{|c|c|c|c|}
\hline Tombol & Fungsi & Tombol & Fungsi \\
\hline \begin{tabular}{|c|} 
Input Data \\
Baru \\
Buka File \\
Simpan File \\
\end{tabular} & $\begin{array}{l}\text { Kelompok tombol ini berfungsi } \\
\text { untuk proses input data program } \\
\text { NC-Code ke dalam PC. }\end{array}$ & $\begin{array}{l}\text { Simulasi } \\
\text { Simulasi }\end{array}$ & 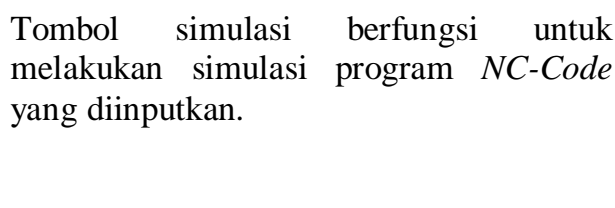 \\
\hline \begin{tabular}{|c|} 
Konpi le \\
Cek Program \\
Laniut \\
Reset \\
\end{tabular} & $\begin{array}{l}\text { Kelompok tombol ini berfungsi } \\
\text { untuk proses pengecekan program } \\
\text { NC-Code dari kemungkinan error. }\end{array}$ & \begin{tabular}{|l|} 
Otomatis \\
Jolonkon \\
Pewno \\
Slop \\
\end{tabular} & $\begin{array}{l}\text { Kelompok tombol ini berfungsi untuk } \\
\text { melakukan eksekusi, pause, dan } \\
\text { menghentikan eksekusi program NC-Code } \\
\text { yang diinputkan. }\end{array}$ \\
\hline $\begin{array}{l}\text { Pemrograman } \\
\text { - Inkrimental } \\
\text { - Absolut }\end{array}$ & $\begin{array}{l}\text { Option button ini berfungsi untuk } \\
\text { memilih metode pemrograman yang } \\
\text { digunakan antara sistem inkrimental } \\
\text { dan sistem absolut. }\end{array}$ & 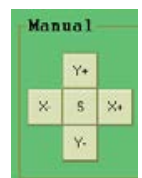 & $\begin{array}{l}\text { Kelompok tombol ini berfungsi untuk } \\
\text { menggerakkan end effector secara manual } \\
\text { (tanpa NC-Code)ke empat arah yaitu arah } \\
\mathrm{X}+, \mathrm{X}-\mathrm{Y}, \mathrm{Y} \text {, dan } \mathrm{Y}-\text {. }\end{array}$ \\
\hline
\end{tabular}


Tabel 3.

Data hasil pengujian linearitas.

\begin{tabular}{cccccccc}
\hline \multicolumn{2}{c}{ Sumbu x Positif $(\mathbf{m m})$} & \multicolumn{2}{c}{ Sumbu x Negatif $(\mathbf{m m})$} & \multicolumn{2}{c}{ Sumbu y Positif $(\mathbf{m m})$} & \multicolumn{2}{c}{ Sumbu y Negatif $(\mathbf{m m})$} \\
\hline Setting & Nilai terukur & Setting & Nilai terukur & Setting & Nilai terukur & Setting & Nilai terukur \\
\hline 50 & 52,63 & 50 & 52 & 50 & 51,5 & 50 & 52 \\
\hline 75 & 77,12 & 75 & 76 & 75 & 77 & 75 & 77 \\
\hline 100 & 102 & 100 & 101 & 100 & 101 & 100 & 103 \\
\hline 125 & 128 & 125 & 126 & 125 & 126 & 125 & 127 \\
\hline 150 & 155 & 150 & 150 & 150 & 150 & 150 & 151 \\
\hline 175 & 178 & 175 & 175 & 175 & 175 & 175 & 177 \\
\hline 200 & 202 & 200 & 201 & 200 & 201 & 200 & 202 \\
\hline
\end{tabular}

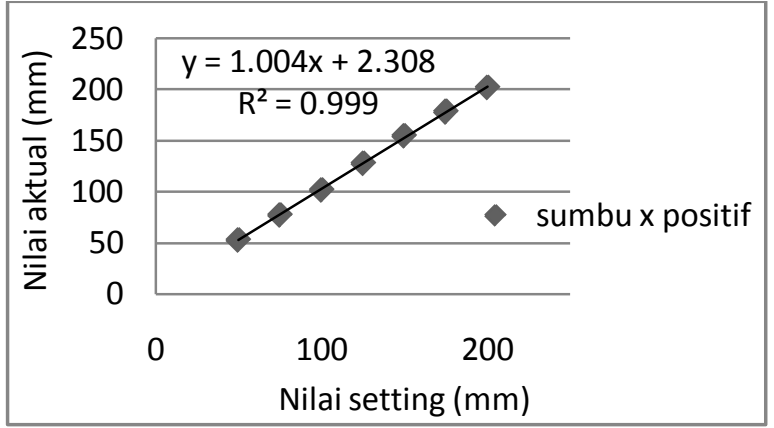

(a)

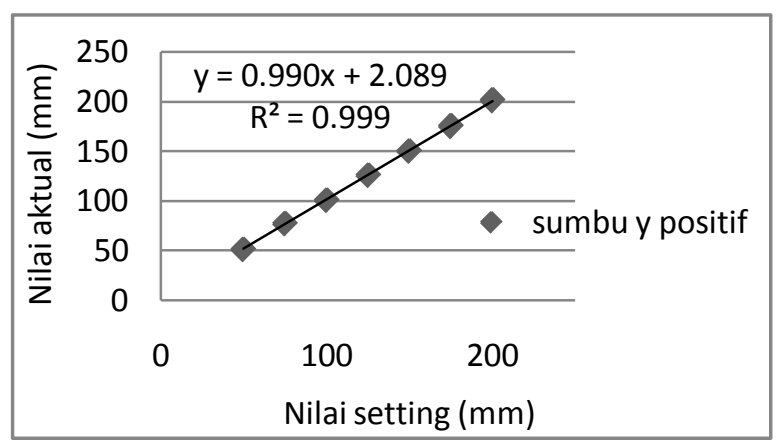

(c)

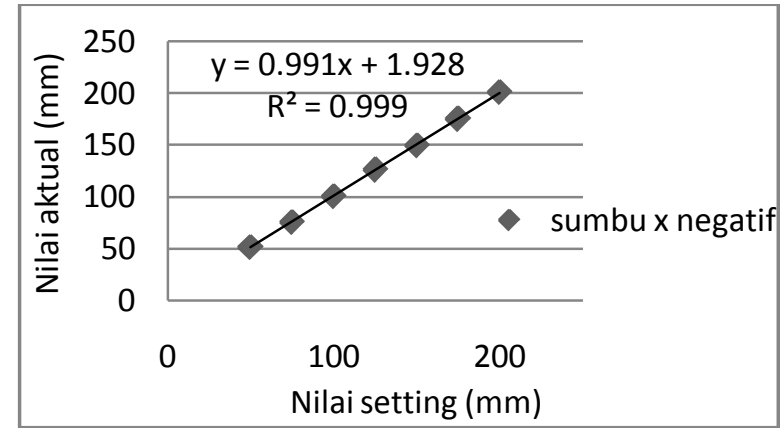

(b)

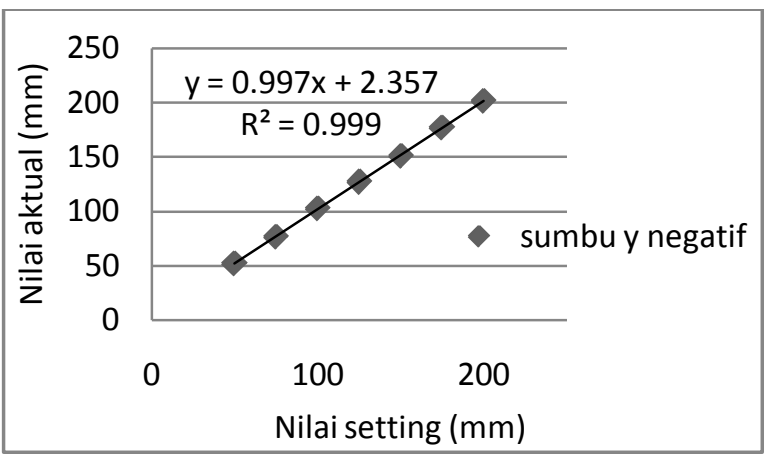

(d)

Gambar 8. Grafik hasil pengujian linearity (a) Pengujian sumbu x positif, (b) Pengujian sumbu x negatif, (c) Pengujian sumbu y positif, (d) Pengujan sumbu y negatif.

Hasil perhitungan regresi linier menunjukkan bahwa untuk gerakan end effector pada arah sumbu x positif (Gambar 8a), sumbu x negatif (Gambar 8b), sumbu y positif (Gambar 8c), dan sumbu y negatif (Gambar 8d) dikatakan linier dengan koefisien regresi linier $r=0,999$. Untuk kondisi ideal, persamaan regresi linier untuk masing-masing arah gerakan ialah $\mathrm{y}=\mathrm{x}$, atau dengan kata lain gerakan aktual yang dilakukan end effector mesin harus sama dengan nilai yang diinputkan ke program. Dari grafik menunjukkan koefisien $\mathrm{x}$ pada masing-masing persamaan sudah mendekati 1. Nilai ini menunjukkan perbandingan antara nilai setting, sudah sama dengan nilai aktualnya. Namun pada masing- masing persamaan terlihat adanya nilai konstanta sebesar 2,308 untuk sumbu x positif, 1,928 untuk sumbu $\mathrm{x}$ negatif, 2,089 untuk sumbu y positif, dan 2.357 untuk sumbu y negatif. Nilai ini menunjukkan adanya rata-rata pergeseran dari nilai setting pada masing-masing sumbu sebesar $2 \mathrm{~mm}$. Hal ini dikarenakan oleh error sistemik dari pembacaan rotary encoder sebagai feed back posisi oleh microcontroller. Untuk memperbaiki akurasi gerakan end effector, nilai ini bisa dimasukkan sebagai nilai koreksi.

Untuk hasil pengujian positioning repeatability pada end effector mesin ditunjukkan pada Gambar 9. 


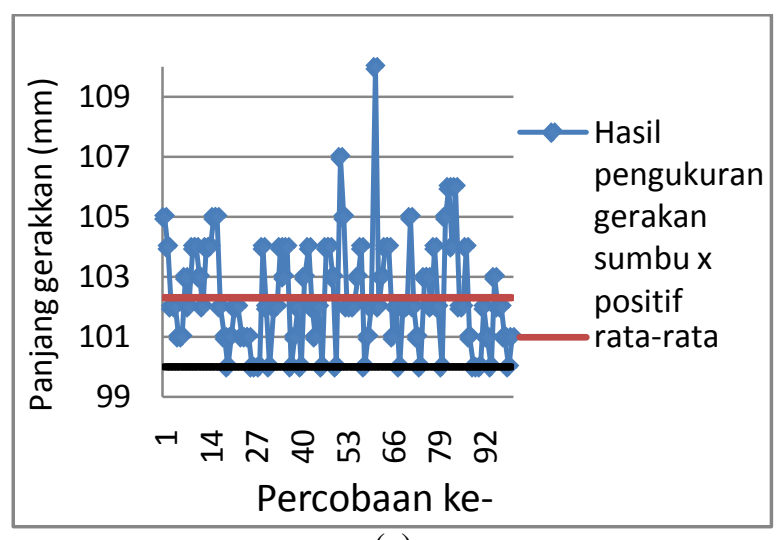

(a)

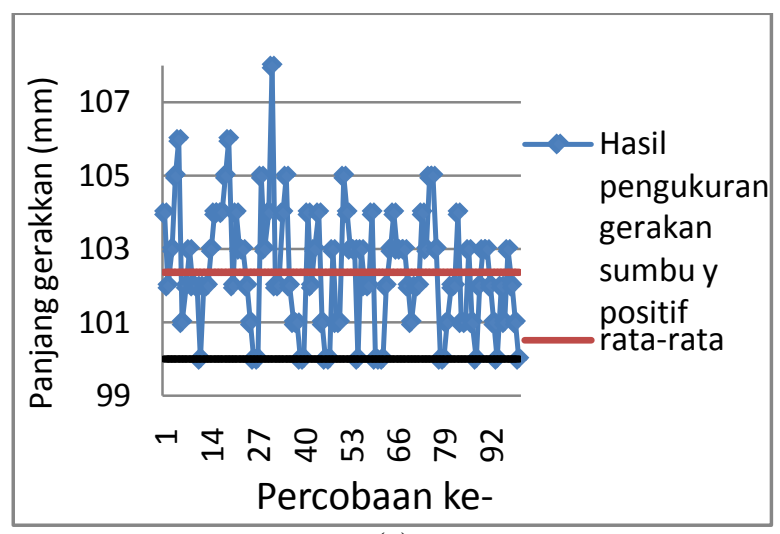

(c)

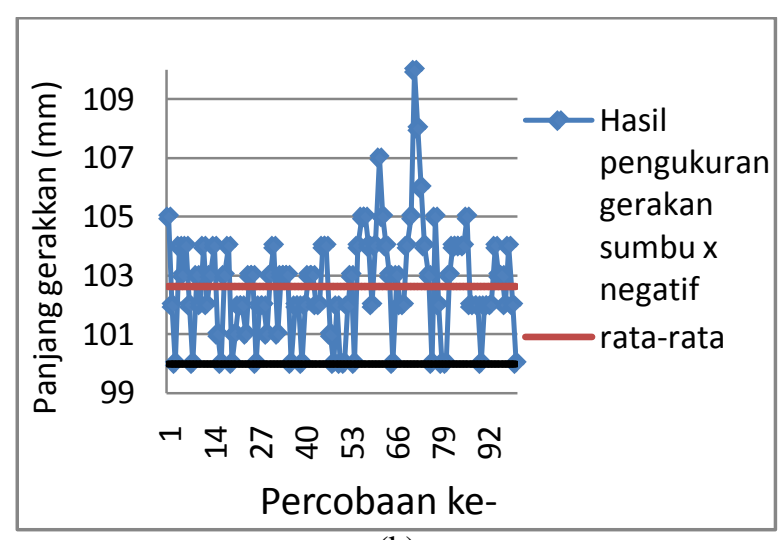

(b)

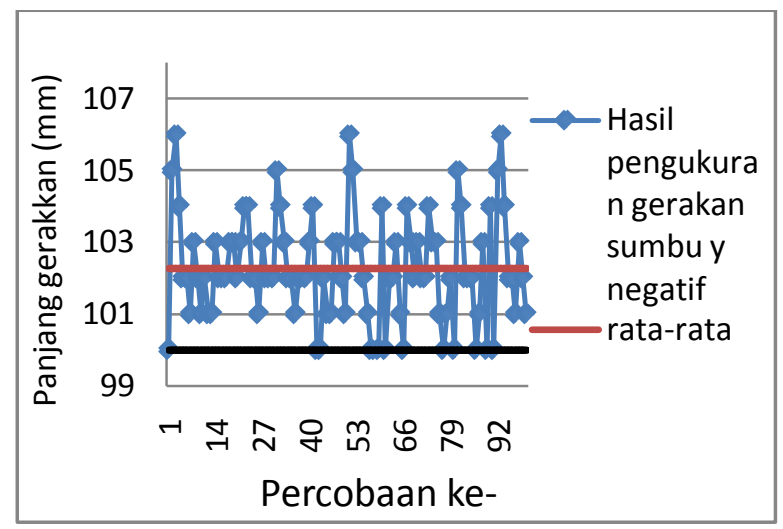

(d)

Gambar 9. Grafik hasil pengujian repeatability (a) Pengujian sumbu x positif, (b) Pengujian sumbu x negatif, (c) Pengujian sumbu y positif, (d) Pengujan sumbu y negatif.

Dari Gambar 9, bisa dilihat hasil pengukuran aktual pergerakan end effector mesin pada pengujian repeatabilitas. Nilai yang diinputkan pada pengujian ini adalah $100 \mathrm{~mm}$ untuk masingmasing arah sumbu. Nilai pergerakkan aktual diukur dan dirata-ratakan dari semua pengulangan. Dari hasil perhitungan nilai ratarata tersebut didapat pergeseran nilai rata-rata terhadap nilai setting sebesar 2,31 mm pada sumbu x positif (Gambar 9a), 2,63 mm pada sumbu x negatif (Gambar 9b), 2,59 mm pada sumbu y positif (Gambar 9c), dan 2,27 mm pada sumbu y negatif (Gambar 9d). Seperti pada pengujian linieritas, pergeseran nilai rata-rata ini menunjukkan adanya error sistemik. Semua nilai pengukuran berada di atas nilai setting menunjukkan kemungkinan error sistemik diakibatkan belum adanya kontrol pengereman yang baik dari kontrol motor, sehingga ketika kontrol memerintahkan untuk berhenti aktuator tidak dapat langsung berhenti seketika sehingga menimbulkan kelebihan pergerakan dari yang diinputkan. Dari hasil perhitungan statistik didapat nilai Standar deviasi 1,82 mm pada sumbu xpositif, $1,84 \mathrm{~mm}$ pada sumbu x negatif, 1,66 mm pada sumbu y positif, dan 1,42 mm pada sumbu y negatif. Nilai ini menunjukkan ketelitian positioning end effector mesin dengan menggunakan sistem kendali ini rata-rata sebesar $\pm 1,82 \mathrm{~mm}$.

Selanjutnya, pada Gambar 10 ditunjukkan hasil dari pengujian kemampuan interpolasi linier dengan menguji kemampuan sistem untuk membentuk pola linier berbentuk bintang segi delapan.

Pola linier (Gambar 10a) diujikan dengan menginputkan NC-Code untuk pergerakan linier dan koordinatnya ke sistem kendali (Gambar 10b). Setelah program di-running, bentuk yang diujikan dapat disimulasikan dan dieksekusi dengan baik. Hasil simulasi pada layar simulasi (Gambar 10c) dan hasil gambar pergerakan aktual end effector mesin (Gambar 10d) menunjukkan bentuk yang sesuai dengan program yang diinputkan. Hal ini menunjukkan algoritma perangkat lunak di PC untuk perhitungan interpolasi linier sudah berfungsi dengan baik dan dapat diimplementasikan dengan baik untuk positioning end effector mesin. Efek dari error sistemik yang didapat dari pengujian linearitas tidak terlihat pada eksekusi intepolasi linier ini. Hal ini dikarenakan nilai error pada semua sumbu sama sehingga nilai error terkompensasi. 


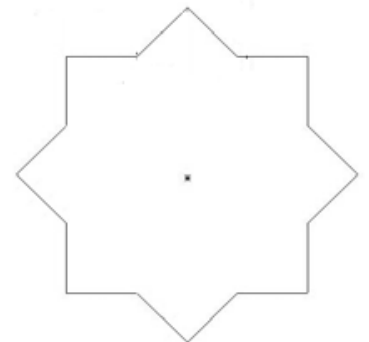

(a)

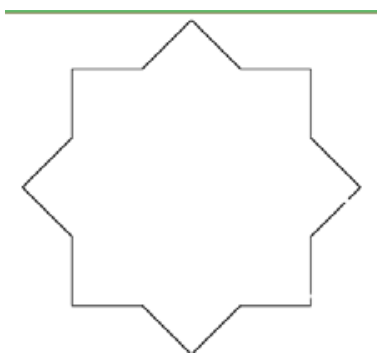

(c)

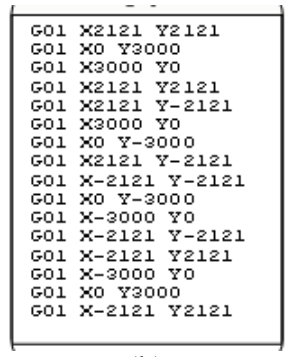

(b)

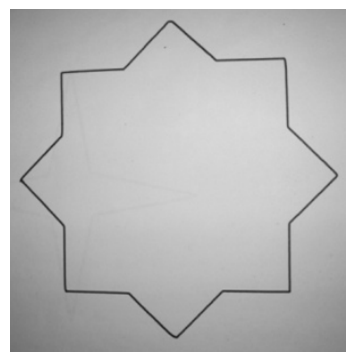

(d)

Gambar 10. Hasil pengujian interpolasi linear(a) Pola linier yang diujikan, (b) Input NC-Code (c) Hasil simulasi di komputer, (d) Hasil gerakan aktual end effector.

Kemudian pada Gambar 11 ditunjukkan hasil dari pengujian kemampuan interpolasi sirkular dengan menguji kemampun sistem untuk membentuk pola sirkular berbentuk cakra. Pola sirkular (Gambar 11a) diujikan dengan menginputkan NC-Code ke sistem kendali

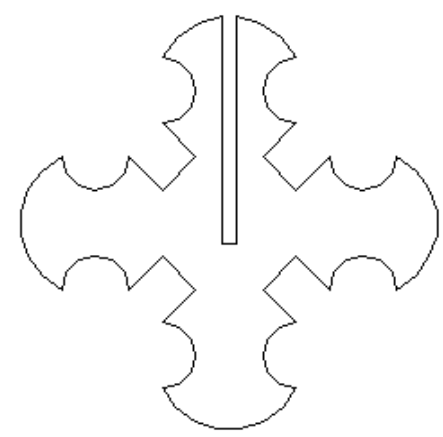

(a)

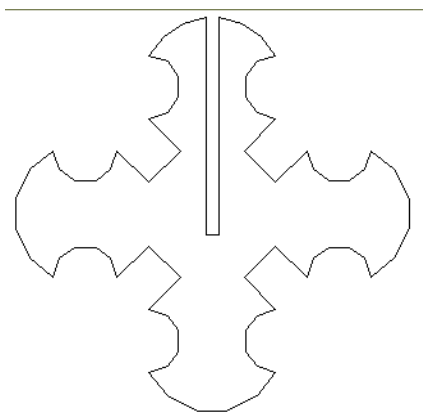

(c)
(Gambar 11b). Hasil simulasi dari program yang diinputkan menunjukkan bentuk yang sesuai dan sempurna (Gambar 11c). Hal ini menunjukkan algoritma perangkat lunak di PC untuk perhitungan interpolasi sirkular sudah berjalan dengan baik.

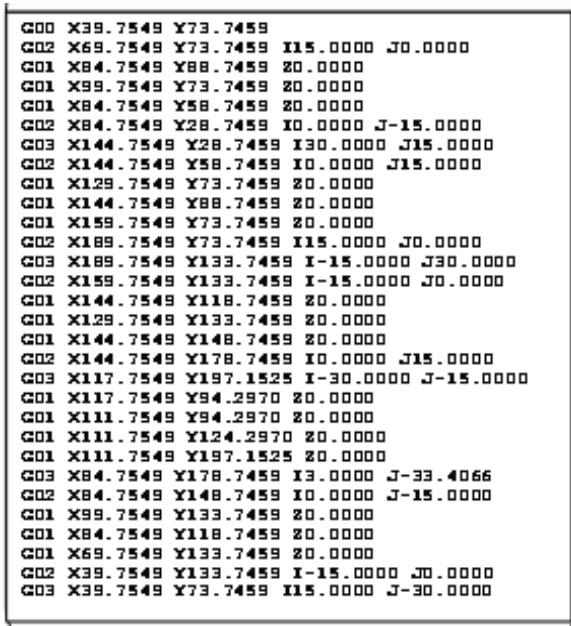

(b)

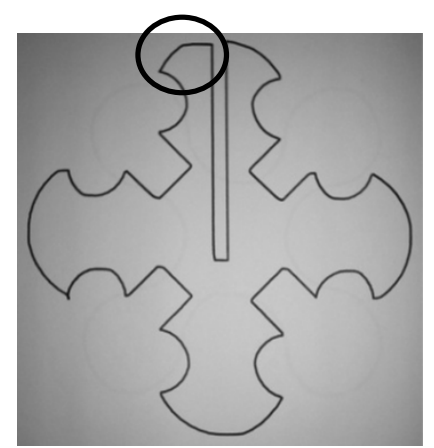

(d)

Gambar 11. Hasil pengujian interpolasi sirkular (a) Pola sirkular yang diujikan, (b) Input NC-Code, (c) Hasil simulasi di komputer, (d) Hasil gerakan aktual end effector. 
Sedangkan pada hasil pergerakan aktual end effector (Gambar 11d), bagian yang dilingkari menunjukkan bentuk yang tidak sempurna dari bagian akhir interpolasi sirkular.Hal ini terjadi dimungkinkan karena adanya error sistemik dari sistem seperti telihat pada pengujian linieritas dan repeatabilitas. Pada pengujian interpolasi linier, efek ini tidak begitu berpengaruh, karena error sistemik pada masing-masing sumbu saling mengkompensasi. Sedangkan pada pengujian interpolasi sirkular pengaruhnya sangat signifikan karena pada perhitungan sirkular menggunakan banyak rumus yang pada masingmasing perhitungannya dapat terjadi pembulatan sehingga pada bagian akhir proses interpolasi, nilai error tidak terkompensasi.

\section{KESIMPULAN}

Pada penelitian ini, telah dihasilkan sistem pengendali router berbasis $\mathrm{CNC}$ untuk flame cutting machine dengan menggunakan personal computer.

Berdasarkan hasil dan analisis, gambar hasil simulasi yang ditampilkan pada layar simulasi sudah sesuai dengan program input yang dimasukkan baik untuk pola linier maupun pola sirkular. Untuk pengujian pergerakan aktual pada end effector, hasil pengujian linearitas menunjukkan sistem memiliki linearitas yang baik dengan koefisien regresi linier 0,99, dan dari pengujian repeatabilitas diperoleh nilai akurasi positioning end effector rata-rata $\pm 1,8 \mathrm{~mm}$. Pembuatan bentuk- bentuk linear sudah dapat dilakukan dengan baik. Sedangkan pembuatan bentuk-bentuk sirkular masih belum sempurna yang kemungkinan disebabkan error sistemik yang belum terkompensasi.

Dari hasil yang diperoleh, dapat disimpulkan bahwa algoritma kendali yang dibuat sudah mampu berfungsi dengan baik. Untuk implementasi di hardware sebenarnya, paremeterparameter dari faktor koreksi yang disebabkab error sistemik bisa dimasukkan dan diujikan untuk memperoleh hasil yang lebih baik terutama pada pembuatan pola-pola sirkular.

\section{UCAPAN TERIMAKASIH}

Penulis mengucapkan terima kasih kepada Bapak Prof. Dr. Masno Ginting, MSc.yang telah banyak memberikan masukan, saran, dan ilmu dalam proses bimbingan penulisan karya tulis ini. Terakhir penulis juga mengucapkan terima kasih kepada Dr. Eng.Estiko Rijanto selaku Kepala Bidang Mekatronik, Pusat Penelitian Tenaga Listrik dan Mekatronik - LIPI, yang telah memberikan bimbingan hingga terselesaikannya penulisan makalah ini.

\section{DAfTAR Pustaka}

[1] Ulsoy, A.G. Koren, Y. 1993 Control of Machining Processes, ASME Journal of Dynamic Systems Measurement, and Control 115 (1993) 301-307.

[2] International Standards Organization,. ISO 14649-1. Datamodel for computerized numerical controllers : part 1, 2003.

[3] 5 Axis CNC Routers, 3 Axis Routers, Used CNC Routers [online]. Available: http://ww.machineks. com/ machines/cncplasma-flamecutters-9, diakses 28 Februari 2011

[4] Pabolu, V.K. Srinivas, S.K.N.H.. Design and Implementation of a Three Dimensional CNC Machine. International Journal on Computer Science and Engineering (IJCSE), 02(08) : 2567-2570, 2010.

[5] X.W. Xu and Newman, S.T.. 2006 Making CNC machine tools more open, interoperable and intelligent-a review of the technologies. Computers in Industry, 57(2) :141-152

[6] Pressman, RS. Numerical control and computer-aided manufacturing, John Wiley \& Sons, Inc. New York, NY, USA, 1977.

[7] Mehta, NK. Machine Tool design, Tata McGraw Hill Company Limited, New Delhi. 1980. 